\title{
Problem Solving Ability: A case study in Postgraduate Mathematics Student
}

\author{
Siti Khabibah, Manuharawati, and Agung Lukito \\ Mathematic's Department, Universitas Negeri Surabaya, INDONESIA \\ sitikhabibah@unesa.ac.id, manuharawati@unesa.ac.id, agunglukito@unesa.ac.id
}

\begin{abstract}
Problem solving is the ability which can be used not only to solve a simple problem but also a complicated problem. It is a skill which can be trained in every level of education. Therefore, teachers are required to be able to trill this ability and an obligation for mathematics teacher to have an excellent problem solving skills. This research aimed to explore the ability of postgraduate students to solve mathematics problems. Mathematics postgraduate student at Universitas Negeri Surabaya had been chosen as a subject. The instrument was developed based on Polya (1973). Firstly, we did literature reviews in order to explore what kind of problem solving test which could be used to mapping student ability. Moreover, we constructed a student's worksheet with high order thinking problem. It had been analysed to find out the student's ability. The result showed that students' ability in solving mathematics problem is bad. Almost $100 \%$ subjects understand about the problem, unfortunately only $50 \%$ of students are able to use the data. It is about $50 \%$ of students are able to connect their knowledge with the problem and only $60 \%$ subjects are able to make a plan and able to implement it.
\end{abstract}

Keywords- Postgraduate Mathematics Student; Problem Solving; Polya.

\section{INTRODUCTION}

In everyday life, everyone must have a problem. It could be a political, social, or even cultural. By using the advancement of Science and Technology, which is getting faster nowadays, one can easily discover the progress and the problems of the world. In the last decade, any information can be reached just in a second through internet. However, selected information should not harm other people, religion, and foundation of the Indonesia philosophy (Pancasila). It is necessary to have the ability to think critically in order to find out which information will give beneficial for us. It is also important to filtering information which can be used to solve any problems. The connection between critical thinking and problem solving ability was proposed by [1]. He states that, in order to solve the problem, it is important to involve higherorder thinking such as visualization, association, abstraction, manipulation, reasoning, analysis, synthesis, and generalization. Meanwhile, [2] declare that problem solving is kind of skill which can be trained.
Problem solving ability is an important thing. It is the ability which can be used not only to solve a simple problem but also a complicated problem. Indonesian government has formally requested about that skill through mathematics teaching process in every level of education. It can be seen in Permendiknas No 22 of 2006 [3] which states that the objectives of teaching mathematics in schools are: (1) understanding the concepts of mathematics, explaining interconnectedness and applying concepts or algorithms, accurate, efficient, and appropriate, in solving problems (2) using reasoning in patterns and traits, performing mathematical manipulations in generalizing, compiling evidence, or explaining mathematical ideas and statements 3 ) solving problems that include the ability to understand problems, designing mathematical models (4) communicating ideas with symbols, tables, diagrams, or other media (5) having an appreciative attitude to the usefulness of mathematics in life, that is having curiosity, attention, and interest in learning mathematics, as well as attitudes tenacious and confident in problem solving. Meanwhile, the teaching of mathematics in schools primarily aims to prepare students to face dynamic world changes by emphasizing logical, rational, and critical reasoning, as well as providing them with skills to be able to use mathematics and mathematical reasoning in solving various problems in everyday life as well as in studying other fields of science [4]

Furthermore, it is a must for mathematics teacher to have an excellent problem solving skills which can be used not only to solve their own problem but also to transfer the problem solving ability to their students. In order to determine a good strategy for preparing teachers in problem solving, firstly, we need to know how expert they are in it.

According to [5], problem solving is a planned process that needs to be done in order to obtain a certain solution of a problem that may not be immediately available. Whereas, [2] argue that problem solving is an attempt to find a way out of a difficulty. Goldstein and Levin define a problem solving as a high-level cognitive process that requires modulation and control over basic or routine skills [6]. In mathematics, there are two types of problems namely the problem of finding and the problem of proof. Students have more difficulties in 
solving the problem of proof than the problem of finding, therefore this paper will discuss about the ability of postgraduate student in solving the problem of proof.

The aim of this research was to figure out the ability of postgraduate students to solve mathematics problems. Postgraduate students in Mathematics education program at Universitas Negeri Surabaya had been chosen who mostly consider as Mathematics teachers in high school.

\section{A. Problem Solving Stages}

Regard to [2], there are four steps to solve the problem: understand the problem, make a plan, carry out a plan, and look back at the completed solution. Polya's problem solving diagram can be seen in the following figure.

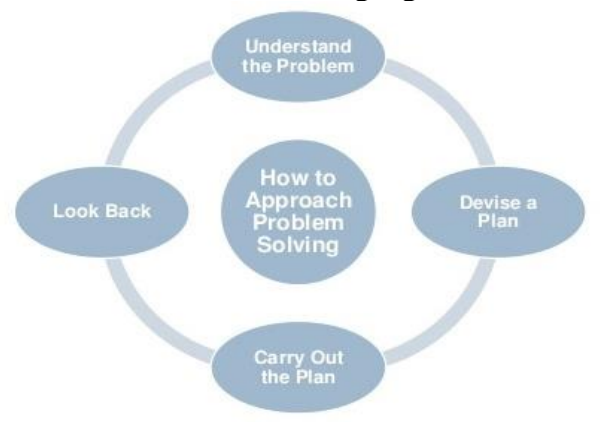

Figure 1: Polya's diagram

The explanation of Polya's diagram can be narrow down as follows:

1. Understand the problem

The first stage of problem solving is understand the problem. Students need to identify what is given and what they are looking for. Some suggestions can help students to understand complex issues, like: (1) to ask questions about what is given and sought, (2) to explain the problem based on their understanding, (3) to link it to the other similar problems, (4) to focus on the part which are important from the problem, (5) to develop the model, and (6) to draw the diagram.

\section{Devise a plan}

Students need to identify the operations involved as well as the strategies needed to solve the given problem. This can be done by students such as: (1) guessing, (2) developing a model, (3) sketching diagrams, (4) simplifying problems, (5) identifying patterns, (6) creating tables, (7) experimenting and simulating, (8) working inversely, (9) testing all possibilities, (10) identifying sub-goals, (11) making analogies, and (12) sorting data/information.

\section{Carry out the plan}

What is applied clearly depends on what has been planned in advance. It also includes the following activities: (1) interpreting the information given into the mathematical form; and (2) executing a strategy during the process and ongoing calculations. In general at this stage students need to retain the chosen plan. If such a plan can't be done, then the student can choose another plan.

\section{Look back}

The following aspects need to be taken into consideration when rechecking steps previously involved in solving the problem, namely: (1) recheck all important information that has been identified; (2) check all calculations already involved; (3) consider whether the solution is logical or not; (4) look at the other alternative solutions; and (5) read the question again and ask yourself if the question has really been answered.

Meanwhile, Nugent and Vitale [7] state that problem solving involves identifying problems, exploring alternative solutions, implementing alternatives or selected solutions, and bringing the result called conclusions. Krulik and Rudnick [8] state that there are five steps that can be done in solving the problem. It can be described as follows:

1) Read. The student activities perform at this stage are to record keywords, to ask other students what is being asked on the problem, or to restate the problem into a more easily understood language.

2) Explore. This process involves searching patterns to determine the concept or the principle of the problem. At this stage, student identifies the given problem, present the problem into an easy-to-understand. The question used at this stage is, "what kind of problem is it"? At this stage, it is usually done by drawing or creating tables.

3) Select a strategy. At this stage, students draw conclusions or hypothesize about how to solve problems encountered based on what has been obtained in the first two stages.

4) Solve the problem. At this stage, all mathematics skills such as counting are done to find an answer.

5) Review and extend. This stage, student re-checks the answer and sees variations from how to solve the problem.

Meanwhile Dewey [8] states the level of problem solving, as follows:

1) Confront the problem. It is the first level for students feel difficulty in solving problem. This process include: realizing the unknown and frustrating on the ambiguity of the situation

2) Define problem. It is the level for students clarify the characteristics of the situation. This stage includes: figuring out known and unknown statements, finding objectives, and identifying conditions which are standard and extreme.

3) Inventory several solution. It is the level for student find the solution. This stage may include: observing the patterns, identifying the steps, and selecting or finding the algorithm.

4) Conjecture consequence of solution. It is the level for student do the plan on the alleged solution. Such as using existing algorithms, collecting additional data, performing needs analysis, reformulating the problem, experimenting for similar situations, and getting results (answers). 
5) Test concequences. It is the level for students test whether the definition of the problem matches the situation. This stage may include: evaluating whether the hypotheses are appropriate, the data are used exactly, the analysis is used correctly, the analysis match the existing data type, the result make sense, and the plan used can be applied in another matter.

\section{METHOD}

This study was conducted on the second year master student in mathematics education program at Universitas Negeri Surabaya. It involved 18 postgraduate students. First, students were asked to solve the given problem and explain the answer afterwards. The problem solving ability of postgraduate students was analyzed by using Polya step. It was including the ability to understand the problem, the ability to make a plan, the ability to solve the problem, and the ability to check the answer.

\section{RESULTS}

Here are some examples of student's work and the analysis of student ability to solve a mathematics problem.

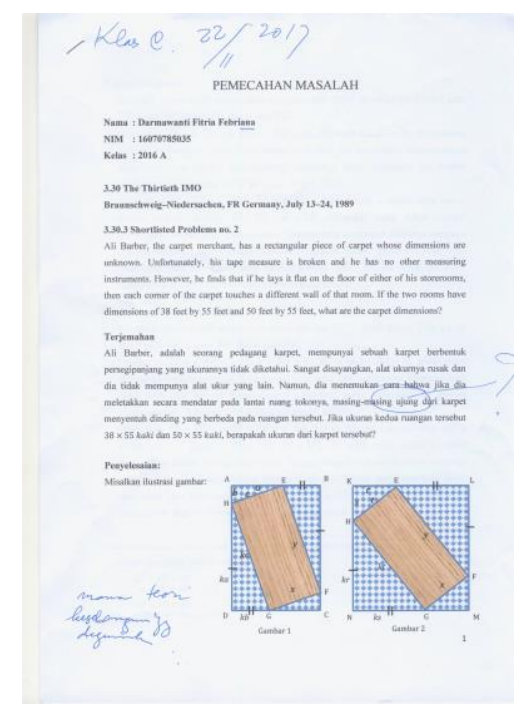

Figure 2:

Regard to figure 2, it can be seen that student couldn't understand about the given problem. This students work was contrary to another student's work. It was about $100 \%$ student understood about the question. They knew exactly what kind of problem they had to solve.

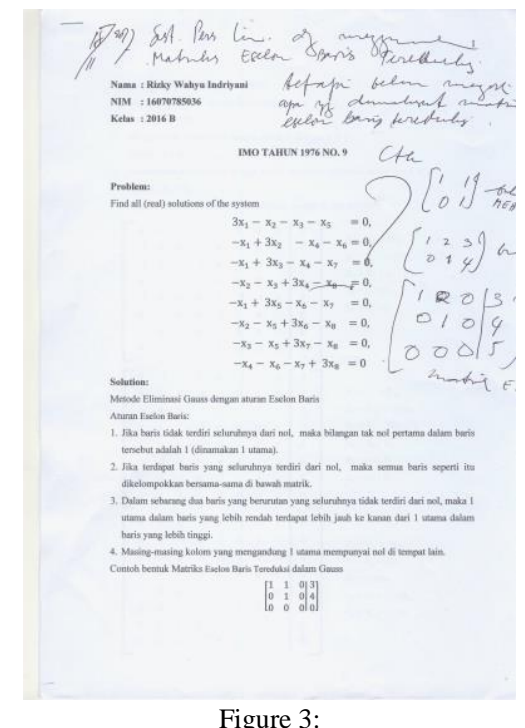

Figure 3 shows that student was not an expert in prerequisites lecture. This student could not solve the given problem because the student does not know about matrix row reducer. He used this method, unfortunately he did not understand about it.

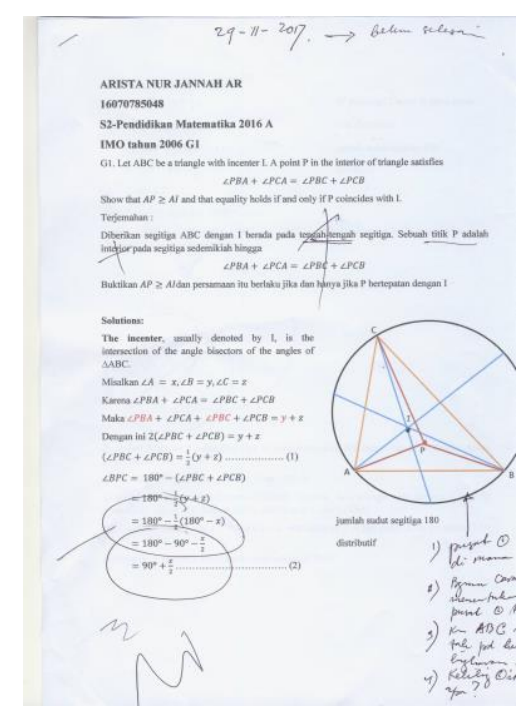

Figure 4.

Regard to figure 4, it can be seen that student did not know about the question. He made an illustration about a triangle $\mathrm{ABC}$ which lied in the circle, however it was not stated in the questions. To make a circle, it was also undefined in advance. Almost 50\% student was able to use information provided in the problem. 


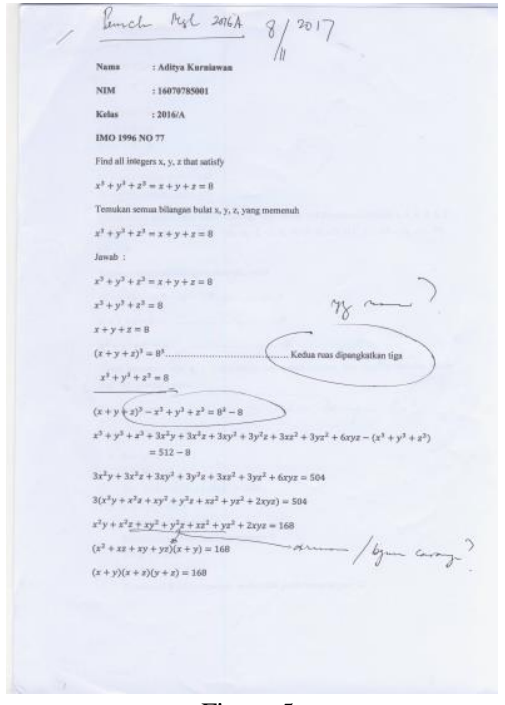

Figure 5:

Figure 5 shows that student's ability could be analyzed as follow:

1. Student made a mistake in subtraction operational.

$$
(x+y+z)^{3}-\left(x^{3}+y^{3}+z^{3}\right)=(x+y+z)^{3}-x^{3}+y^{3}+z^{3} .
$$

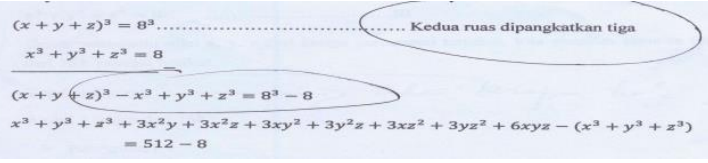

Figure 6:

2. Student did not use a general mathematics role

$3 x^{2} y+3 x^{2} z+3 x y^{2}+3 y^{2} z+3 x z^{2}+3 y z^{2}+6 x y z=50$

$3\left(x^{2} y+x^{2} z+x y^{2}+y^{2} z+x z^{2}+y z^{2}+2 x y z\right)=504$

$x^{2} y+x^{2} z+x y^{2}+y^{2} z+x z^{2}+y z^{2}+2 x y z=168$

$\left(x^{2}+x z+x y+y z\right)(x+y)-168$

$(x+y)(x+z)(y+z)=168$

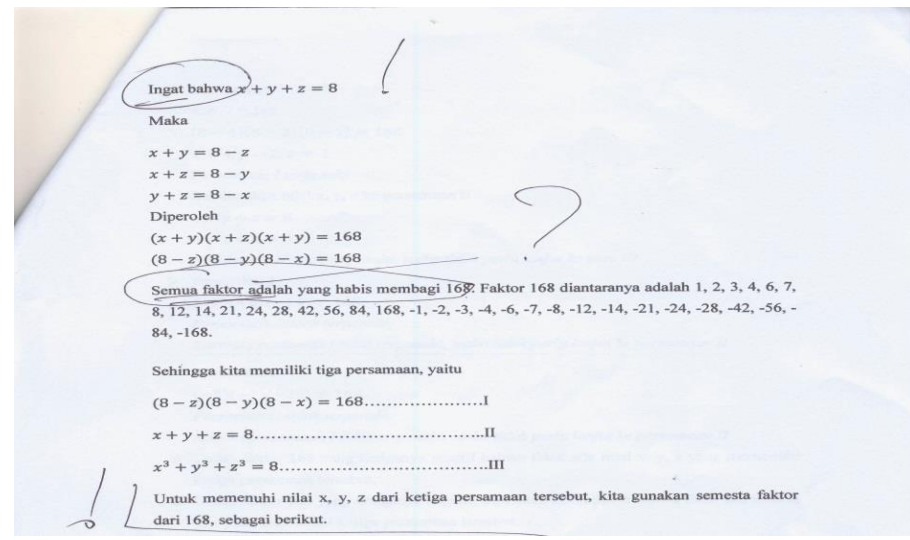

Figure 7:
It was about $50 \%$ of student was able to connect an initial knowledge with the given problem. Regard to the analysis, it was about $60 \%$ of student who have ability to implement the settlement plan. Moreover, it can be summarized that student's ability to re-check the answer was low

\section{CONCLUSION}

Regard to the analysis and results shows that the ability of postgraduate students in solving mathematics problem were bad. It was supported by these data. (a) The ability to understand the problems. Almost 100\% students understand what was being asked in the problem. Approximately only $50 \%$ of students were able to use the data/information. (b) The ability to make a plan to solve the problem was low. Only $50 \%$ of students were able to connect their knowledge with the problem. (c) The ability to implement the settlement plan was low, about $60 \%$ of students who were able to make a plan and able to implement it. (d) The ability to re-check the answer was low. Regard to the students who have successfully implemented a settlement plan, only about $60 \%$ were re-check the answer.

\section{REFERENCES}

[1] J. Kirkley, Principles for Teaching Problem Solving, Plato Learning Center. (Online), (http://www.plato.com/downloads/papers/paper 04.pdf), 2003.

[2] G. Polya, How to Solve It, Princenton University Press. New Jersey Princenton, 1981.

[3] Depdiknas, Peraturan Menteri Pendidikan Nasional Nomor 22 Tahun 2006 TentangStandar Isi untuk Satuan Pendidikan Dasar dan Menengah, Jakarta: Kemendiknas-Depdiknas, 2006.

[4] S. Hadi, Pendidikan Matematika Realistik dan Implementasinya, Banjarmasin: Tulip, 2005.

[5] N. S. Saad and S. A. Ghani, Teaching Mathematics in Secondary School:

Theories and Practices, Perak: Universiti Pendidikan Sultan Idris, 2008.

[6] L. Misu and Rosdiana, "Pengembangan Teori Pembelajaran Perilaku Dalam Kaitannya Dengan Kemampuan Pemecahan Masalah Matematik Siswa Di SMA", Prosiding Seminar Nasional Matematika dan Pendidikan Matematika, 2013.

[7] M. Fahim and M. Pezeshki, "Manipulating Critical Thinking Skills in Test Taking", International Journal of Education, vol. 4, no. 1, pp. 153160, 2012.

[8] J. Carson, "A Problem With Problem Solving: Teaching Thinking Without Teaching Knowledge", The Mathematics Educator, Vol. 17, No. 2, pp. 7-14, 2007. 